\title{
Regulation of growth and energetics of a marine bacterium by nitrogen source and iron availability
}

\author{
David L. Kirchman*, Kimberly A. Hoffman, Richard Weaver, David A. Hutchins \\ College of Marine Studies, University of Delaware, Lewes, Delaware 19958, USA
}

\begin{abstract}
This study examined the effect of nitrogen source and iron availability on growth rates, electron transport system (ETS) activity and growth efficiency for the marine gamma-proteobacterium Vibrio harveyi. We found that all 3 parameters increased with increasing iron concentration and varied as a function of nitrogen source (amino acids, ammonium, and nitrate). At low iron concentrations, growth rates were highest and lowest in the amino acid and nitrate media, respectively. Rates were similar for the amino acid and the ammonium plus glucose media with sufficient iron $(>20 \mathrm{nM})$. Growth rates were lowest when nitrate was the nitrogen source, regardless of iron concentration. ETS activity per cell in the different media mostly followed the pattern in growth rates, although ETS activity for cells using nitrate was even lower than would have been predicted from the growth rate data. Growth efficiencies for iron-sufficient cells did not vary substantially among cells using the 3 nitrogen sources ( 45 to $55 \%$ ), but they were substantially higher than growth efficiencies of iron-depleted cells $(<10 \%)$. In media without added iron, cells grown on nitrate had the lowest growth efficiency, $>2$-fold lower than iron-stressed cells using ammonium or amino acids as nitrogen sources. Although results from any single cultured bacterium should be applied cautiously to natural microbial assemblages, our data may help explain the low growth efficiencies and growth rates in iron-limited oceanic regimes with high nitrate but low chlorophyll concentrations.
\end{abstract}

KEY WORDS: Fe limitation - Inorganic $\mathrm{N}$ assimilation . Growth efficiency $\cdot$ Vibrio

Resale or republication not permitted without written consent of the publisher

Heterotrophic bacteria can account for a large fraction of inorganic nitrogen and iron uptake in the oceans. Several studies have shown that nearly $50 \%$ of nitrate and ammonium uptake can be due to these microbes in many marine habitats (reviewed by Kirchman 2000), and Schmidt \& Hutchins (1999) found that the bacterial size fraction accounted for 10 to $57 \%$ of iron uptake along a transect from iron-rich coastal waters to the iron-limited subarctic Pacific Ocean.
There is little evidence that marine heterotrophic bacteria are ever limited by nitrogen (reviewed by Thingstad 2000, but see Seitzinger et al. 2002), but the situation with iron limitation is less clear. Direct limitation of bacterial growth by iron has been reported in a single Southern Ocean study (Pakulski et al. 1996), but other investigations have suggested that even in high nutrient-low chlorophyll (HNLC) regimes, the supply of organic carbon is the proximate limiting factor of heterotrophic bacteria (Church et al. 2000, Kirchman et al. 2000). The effect of nitrogen source and low iron concentrations on bacterial energetics is largely unknown.

Some data and theoretical considerations indicate that the nitrogen source could impact bacterial growth rates and growth efficiencies. Growth rates of cultured bacteria are often highest in complex media and in media supplemented by amino acids (Marr 1991), but this organic nitrogen effect was not observed for a mixed culture of marine bacteria (Goldman \& Dennett 2000). Growth on amino acids may not be faster if the transport costs of using several amino acids exceed the energetic advantage of avoiding amino acid synthesis, which is necessary for cells growing on ammonium and a suitable carbon source. The energetic costs of using nitrate, which must be reduced to ammonium before use in biosynthesis, seem clearer, although we are not aware of any study examining growth rates of bacteria using nitrate as a nitrogen source. Carbon growth efficiencies are similar when bacteria use glucose plus ammonium or amino acids (Goldman \& Dennett 2000), but the impact of nitrate use is not known.

Iron limitation should also affect the growth efficiencies of bacterial assemblages, based on theoretical considerations and on a few experiments with cultured marine bacteria. Tortell et al. (1996) showed that iron deficiency decreased the growth efficiency of 3 of the 5 bacterial strains they tested. Low iron concentrations apparently affected the iron-rich electron transfer sys- 
tem (ETS) which is essential for ATP synthesis in aerobic heterotrophic bacteria. Unfortunately, interactions between the nitrogen source and iron availability were not examined.

The purpose of this study was to further explore the impact of iron limitation on bacterial energetics and to examine interactions between the nitrogen source and iron concentrations in determining bacterial growth. In addition to impacts on ETS activity, low iron concentrations could affect bacterial growth via effects on nitrate use. Nitrate assimilation depends on 2 enzymes, nitrate reductase and nitrite reductase, that require iron as a cofactor (reviewed by Tortell et al. 1999). Consequently, we hypothesized that growth rates would be lower for iron-stressed cells using nitrate rather than amino acids or ammonium as nitrogen sources. We found that growth rates and growth efficiency of the marine bacterium Vibrio harveyi decreased with decreasing iron concentrations and that both growth parameters were lowest for iron-stressed cells using nitrate.

Materials and methods. The experiments were conducted with the gamma proteobacterium Vibrio harveyi because it readily grew in the media tested here and because other aspects of its metabolism have been examined extensively (e.g. Montgomery \& Kirchman 1993, Bassler et al. 1994, Svitil et al. 1997). Preliminary experiments indicated that a strain of the alphaproteobacterium Roseobacter sp. grew too poorly in these media to be practical for this study. The BB7 strain of $V$. harveyi was inoculated into LM broth (Ausubel et al. 1992) and grown overnight before each experiment. One aliquot of $1.5 \mathrm{ml}$ was centrifuged for $10 \mathrm{~min}$ at $10000 \mathrm{rpm}$ and washed twice in iron-free media. The cell pellet was then resuspended in an iron-free medium supplemented with AQUIL, an artificial culturing medium (Price et al. 1989) and held under iron-free conditions for $4 \mathrm{~h}$ prior to the beginning of each experiment. Experimental cultures were inoculated with approximately $10^{5}$ cells ml-1 Cells were enumerated with acridine orange or DAPI staining and epifluorescence microscopy and by measuring the optical density at $600 \mathrm{~nm}$.

For experiments examining growth on inorganic nitrogen, bacteria were grown in a chelexed minimal medium consisting of $1.5 \mathrm{mM}$ glucose (9 mM C), $1.5 \mathrm{mM} \mathrm{NH}_{4}{ }^{+}$or $\mathrm{NO}_{3}{ }^{-}$, and $0.15 \mathrm{mM}$ phosphate added to $0.2 \mu \mathrm{m}$ filtered surface Sargasso Sea water. The amino acid medium ( $9 \mathrm{mM} \mathrm{C}$ ) contained the amino acids representative of an Escherchia coli cell (Schulz \& Schirmer 1979) and $0.15 \mathrm{mM}$ phosphate. This medium was passed over Chelex columns to remove all trace metals, after which AQUIL trace metals without iron or EDTA were added at standard concentrations (Price et al. 1989) along with various concentra- tions of iron (see 'Results'). Media were sterilized by microwaving 4 times at $1200 \mathrm{~W}, 3$ min each time (Keller et al. 1988). In media without added iron ('ironfree media'), concentrations of iron were undetectable $(\leq 1 \mathrm{nM}$ ) by electrochemical methods (Van den Berg et al. 1991).

ETS activity was assessed by following the reduction of 2-(4-iodophenyl-3-(4-nitrophenyl)-5-phenyl-tetrazolium (INT) (Packard \& Williams 1981). From the cell cultures, $10 \mathrm{ml}$ aliquots were removed and centrifuged for $10 \mathrm{~min}$ at $10000 \mathrm{rpm}$. Cells were resuspended in homogenization buffer and sonicated for $4 \mathrm{~min}$. The resulting solution was centrifuged for $10 \mathrm{~min}$ at $10000 \mathrm{rpm}$, and $1 \mathrm{ml}$ of the supernatant was added to $3 \mathrm{ml}$ of substrate buffer. After $1 \mathrm{ml}$ of INT stock solution (100 mg INT in $50 \mathrm{ml}$ Milli-Q water) was added, the solution was incubated for $10 \mathrm{~min}$ at room temperature. The optical density was measured at $490 \mathrm{~nm}$ and then divided by cell numbers to obtain activity per cell.

The growth efficiency of Vibrio harvey in the 3 media was estimated by following the assimilation and respiration of either ${ }^{14} \mathrm{C}$ amino acids or ${ }^{14} \mathrm{C}$ glucose added to the amino acid or inorganic nitrogen media. After inoculation, $0.6 \mu \mathrm{Ci}$ of the appropriate ${ }^{14} \mathrm{C}$ compound was added to $10 \mathrm{ml}$ of media. Cultures were allowed to reach early stationary phase, after which they were acidified and the evolved ${ }^{14} \mathrm{CO}_{2}$ was trapped in a basic scintillation cocktail (Crawford \& Crawford 1976). To determine uptake and biomass production, the sample was also filtered $(0.22 \mu \mathrm{m}$ nitrocellulose filters), and the filter was rinsed twice with sterile media. Growth efficiency was then calculated from $R \mathrm{~b} /(R \mathrm{r}+R \mathrm{~b}) \times 100$, where $R \mathrm{~b}$ is radioactivity in biomass collected on the filter and $\mathrm{Rr}$ is the respired ${ }^{14} \mathrm{CO}_{2}$. Unlike field studies, growth efficiencies determined with ${ }^{14} \mathrm{C}$-labeled compounds depend only on the assumption that the labeled and unlabeled compounds are used similarly. Isotopic equilibrium was reached, since cells took up the radiolabeled carbon source over at least 4 generations (for the slowest growth rate) before growth efficiencies were measured.

Results. Growth rates and ETS activity: We hypothesized that bacterial activity would depend on both iron concentrations and nitrogen source, because both iron and the form of nitrogen used for growth are likely to affect cellular energetics. To test this hypothesis, various growth parameters of the marine bacterium Vibrio harveyi were measured in batch cultures in which iron concentrations and the nitrogen source varied. A sample growth curve for cells growing on amino acids at different iron concentrations is shown in Fig. 1. The concentration of iron in the 'iron-free' media was below detection $(<1 \mathrm{nM})$, but some growth was measurable after a lag period (Fig. 1) even when iron was not added, presumably due to trace iron contamination 


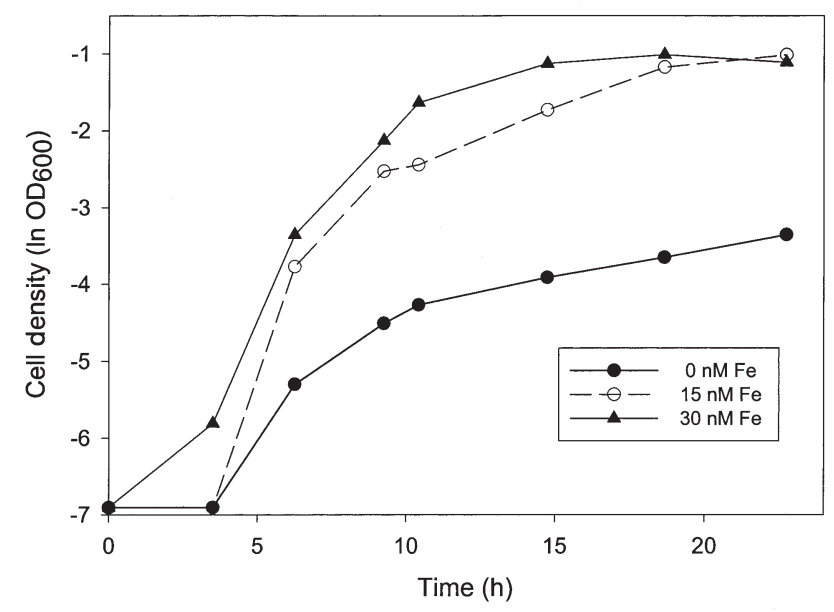

Fig. 1. Vibrio harveyi. Growth of cells grown on amino acids amended with 0,15 or $30 \mathrm{nM}$ of iron. Average of 2 replicate bottles is shown. Data are example of 3 experiments. Growth was monitored by absorbance at $600 \mathrm{~nm}\left(\mathrm{OD}_{600}\right)$

or cellular iron stored during previous growth of the stock culture in the iron-replete medium. Nevertheless, growth and other metabolic parameters did vary with concentrations of added iron (see below), indicative of iron limitation.

Growth rates of Vibrio harveyi varied significantly as a function of both nitrogen source and iron concentrations (Fig. 2; $\mathrm{p}<0.05$, ANOVA). The average growth rate in the amino acid medium increased by about 2-fold as iron was added up to $20 \mathrm{nM}$ (Fig. 2); the increase was statistically significant until about $20 \mathrm{nM}$ $\left(r^{2}=0.46\right.$ for a linear regression of growth rate vs Fe concentration; $\mathrm{p}<0.005)$. Growth rates seemed lower in 30 and $50 \mathrm{nM}$ than in $20 \mathrm{nM}$ of iron, but this difference was not statistically significant (Student's $t$-test, $\mathrm{p}>0.05)$. Growth rates of cells using ammonium also increased as more iron was added up to $10 \mathrm{nM} \mathrm{Fe}$. In contrast, growth on nitrate plus glucose remained uniformly low until $10 \mathrm{nM}$ Fe was added (Fig. 2).

Growth rates were highest with amino acids, especially for low iron concentrations $(\leq 20 \mathrm{nM})$, even though organic carbon and nitrogen concentrations were similar for all treatments. The bacterium grew at least 2-fold faster on amino acids than on ammonium or nitrate in low iron concentrations (Fig. 2). Growth rates on amino acids were higher than on nitrate for all iron concentrations, but rates were similar for amino acid and ammonium-grown cells when iron concentrations were $\geq 30 \mathrm{nM}$. Growth rates for ammoniumgrown cells were either higher than rates for nitrategrown cells $(2,5,30$ and $50 \mathrm{nM}$ iron) or the same $(0,10,15$, and $20 \mathrm{nM}$ iron).

The activity of the electron transfer system at mid$\log$ phase mostly followed growth rates and varied as a

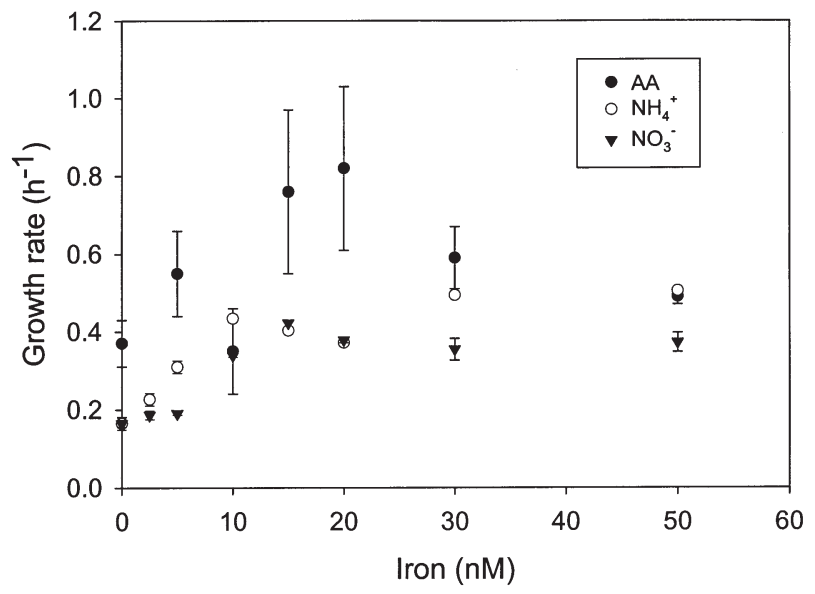

Fig. 2. Vibrio harveyi. Growth rate of cells grown on amino acids (AA), ammonium or nitrate as a function of iron concentration. Glucose was the carbon source for ammonium and nitrate treatments. Rates are from 1 experiment, but are representative of 3 or more experiments. SE bars calculated from linear regression analysis of $\ln$ (cell numbers) versus incubation time

funtion of $\mathrm{N}$ source and iron concentrations. ETS activity per cell was lowest in the absence of added iron, regardless of the $\mathrm{N}$ source (Fig. 3), and increased by about 10 -fold when $30 \mathrm{nM}$ Fe was added to the amino acid and ammonium medium. ETS activity per cell also increased in the nitrate media when iron was added, but the increase was only about 2 -fold $(21.5 \pm 5.6$ vs $8.5 \pm 1.1 \mathrm{SD}$, arbitrary units). The ETS activity of nitrate-grown cells was substantially lower than the activity of cells growing on amino acids or ammonium under iron-replete conditions.

Growth efficiency: The growth efficiency of Vibrio harveyi with added iron (50 nM) was substantially higher than of iron-starved cells ( 45 to $55 \%$ vs $<10 \%$ ), regardless of the nitrogen source (Fig. 4). The experiment was repeated 3 times, with similar results. Growth efficiency did not differ significantly $(p>0.05)$ in the $3 \mathrm{~N}$ media when cells were iron-replete, but did vary significantly for iron-starved cells using different nitrogen sources. The growth efficiency of cells growing on reduced nitrogen (amino acids or ammonium) was about 8-fold higher than that for cells using nitrate plus glucose when no iron was added to the media ( $p<0.05$; Student's $t$-test). Iron starvation led to low growth efficiencies, but forcing cells to grow on nitrate as well as low iron concentrations led to the lowest efficiencies.

Implications for understanding elemental cycles in the oceans: Oceanic prokaryotic and eukaryotic microbes survive and reproduce in a complex mixture of nutrients, nearly all of which occur in very low concentrations even when only a single element, such as nitrogen or iron, is presumed to limit biomass production. It is surprising how little we know about the 


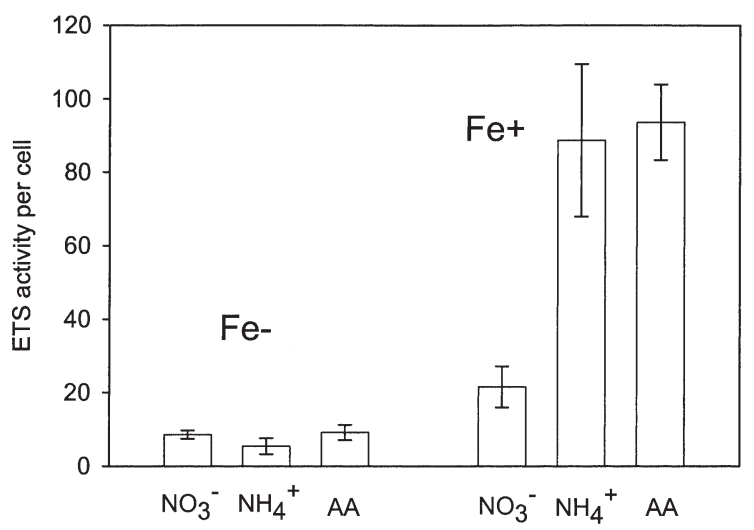

Fig. 3. Vibrio harveyi. Electron transfer system (EST) activity per cell of cells grown on different nitrogen sources under low (0 nM: $\mathrm{Fe}-$ ) or high $(30 \mathrm{nM}: \mathrm{Fe}+)$ iron concentrations. EST activity expressed as absorbance per cell multiplied by $10^{10}$ to give convenient units. Data are averages \pm SD of 3 replicates

mechanisms by which microbes cope with these low concentrations and about their impact on microbial processes. Bacterial energetics is an active field in bioengineering (e.g. Christiansen \& Nielsen 2002), and the regulation of bacterial growth rates by organic carbon has been examined for several decades (e.g. see review by Marr 1991). However, few studies have investigated the impact of nitrogen source and iron on bacterial growth. Results from experiments with cultured bacteria should be applied only cautiously to natural bacterial assemblages, one reason being that no cultured bacterium (with the possible exception of SAR11: Rappe et al. 2002) can be considered 'representative' of all uncultured marine bacteria. Still, results from experiments such as those reported here should illuminate basic principles of bacterial energetics that apply to many, if not all, marine microbes.

The present results support our original hypothesis about the effect of nitrogen source and iron availability on bacterial growth and growth efficiency. Growth rates of the marine bacterium tested here, Vibrio harveyi, were highest on amino acids and lowest on nitrate plus glucose. These results are consistent with previous studies on natural microbial assemblages (e.g. Kirchman et al. 1994) that demonstrated the preference of heterotrophic bacteria for reduced nitrogen sources (organic nitrogen or ammonium) over nitrate (see review by Kirchman 2000). Surprising was the fact that growth on nitrate was poor even when organic carbon concentrations were very high. The growth efficiency of even iron-replete cells using nitrate plus glucose was lower than that for ammonium plus glucose-grown cells, although the difference $(25 \%)$ was less than would be expected ( $56 \%$ ) based on a theoretical model of bacterial energetics (Vallino et al. 1996).

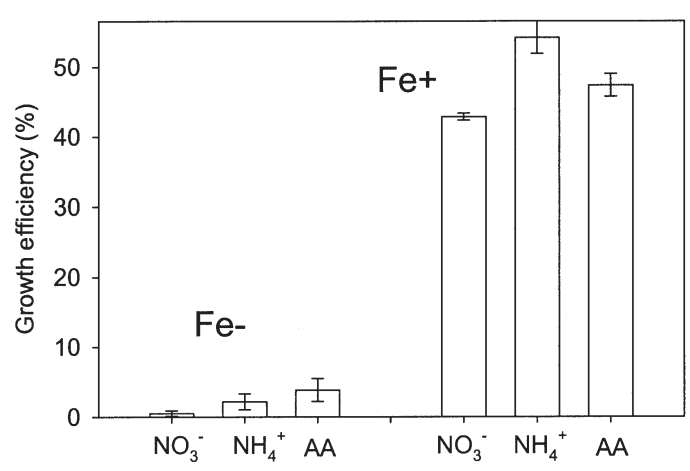

Fig. 4. Vibrio harveyi. Carbon growth efficiency of cells grown on different nitrogen sources and iron concentrations. Nitrogen source had no significant effect on Fe-replete cells $(\mathrm{Fe}+)$, but the growth efficiency of Fe-deficient cells (Fe-) growing on nitrate was significantly lower than of Fedeficient cells grown on ammonium or amino acids (AA). Data are average $\pm \mathrm{SE}$ of 5 replicates, and are representative of 3 experiments

Therefore, the energetic cost of nitrate use was compensated partially by increased organic carbon use relative to biomass production (thus resulting in a lower growth efficiency), but nitrate use still led to low growth rates despite high organic carbon concentrations. Cell yields (cells per ml at early stationary phase) were also lowest in the nitrate media (results not shown), suggesting that grazing by bacterivores may be impacted when nitrate is the major nitrogen source for heterotrophic bacteria.

Another measure of energetics, ETS activity, appeared to be a function of both growth rate and growth efficiency. Similar to the results of Tortell et al. (1996), there was a high correlation between ETS activity and growth rate in our data $(\mathrm{r}=0.88 ; \mathrm{n}=6 ; \mathrm{p}<0.05)$, but the relationship was less close than suggested by that correlation. Unlike growth rates, the ETS activity of irondepleted cells was similar for all 3 nitrogen sources. Iron-depleted cells had lower growth rates, growth efficiencies and ETS activity than iron-replete cells, but the difference was much larger for the latter 2 parameters than for growth rates. In cases when growth rate and ETS activity do not covary, a portion of ETS activity may be devoted to energy production uncoupled from growth. This hypothesis may explain why the ETS activity of Fe-replete cells was much lower (nearly 5 -fold) in the nitrate plus glucose medium than in the other 2 iron-replete media; the difference in ETS activity was much larger than the difference in growth rate, and was not seen at all in the growth efficiency data. These data indicate that there is no simple relationship between growth efficiency, growth rates, and cellular energetics as measured by ETS activity. 
Our results confirm those of Tortell et al. (1996), who found that iron limitation led to lower growth efficiencies in 3 of the 5 strains they examined. Of these 3 strains, the average growth efficiency was $37 \%$ for iron-sufficient cells versus $19 \%$ for iron-deficient cells. Iron had an even larger impact (nearly 10-fold) on the growth efficiency of Vibrio harveyi, which was $<10 \%$ for iron-deficient cells regardless of nitrogen source. The reduction in growth efficiency arising from iron deficiency in our experiments was even larger than that seen when microbes are limited by ammonium or potassium (Neijssel et al. 1996), perhaps because of the direct impact of iron deficiency on ETS activity. However, the results of Tortell et al. (1996) and the present study suggest that bacterial strains differ greatly in their sensitivity to low iron concentrations. Whether iron requirements of uncultured bacteria vary as a function of phylogenetic group or habitat (as do phytoplankton iron requirements: Brand 1991, Sunda \& Huntsman 1995), is currently unknown (Hutchins et al. 2001).

Our results may help explain the low growth efficiency (ca. $15 \%$ ) thought to be common in open-ocean habitats (del Giorgio \& Cole 2000). This low growth efficiency is usually explained by the quality and quantity of dissolved organic material (DOM) available for supporting heterotrophic bacterial growth, but because iron concentrations in surface waters are very low in open-ocean regimes (Johnson et al. 1997), iron may also impact growth efficiencies and other aspects of bacterial energetics even when biological production is not iron limited. Low concentrations of other inorganic nutrients, such as phosphate, that limit bacterial growth in some oceanic regimes (Thingstad 2000) could also impact growth efficiencies (Neijssel et al. 1996). Even organic carbon-limited heterotrophic bacteria have to cope with low concentrations of iron and other inorganic nutrients. The impact of low inorganic nutrient concentrations on growth efficiency and other aspects of bacterial energetics is probably not revealed by standard bioassays for determining which element limits growth of heterotrophic bacteria. The short duration of bioassays (a couple of days at most, which is equivalent to only 1 or 2 generation times) complicates attempts to observe any secondary effects, such as enhanced growth due to changes in growth efficiency following addition of an inorganic nutrient.

The effect of nitrogen source and iron availability is perhaps most important in HNLC regimes, such as the Southern Ocean, and is especially critical in global climate-change models (Sarmiento \& LeQuere 1996, Sarmiento et al. 1998). Nitrate concentrations are high in HNLC regimes, but iron availability is low and limits primary production (Martin et al. 1991). In one HNLC regime, the subarctic Pacific Ocean, hetero- trophic bacteria account for a large fraction of nitrate uptake and rely on it as a nitrogen source, along with free amino acids and ammonium (Kirchman \& Wheeler 1998). Our laboratory experiments suggest that low iron concentrations prevent even more nitrate use by heterotrophic bacteria in the subarctic Pacific, and probably in other HNLC oceans. The combination of high nitrate concentrations but low iron availability could lead to low bacterial growth rates in these HNLC systems. It is unclear, however, whether growth efficiencies are any lower in HNLC regimes than in ironreplete waters (Sherry et al. 1999). Some of the lowest bacterial growth rates have been measured in HNLC regimes (Ducklow 2000), but these low rates could be due to insufficient DOM rather than insufficient iron (Church et al. 2000, Kirchman et al. 2000). Further work is needed to explore these issues in greater detail and to determine the interactions among organic carbon, nitrogen source and iron in regulating the growth and energetics of oceanic bacterial communities.

Acknowledegments. We thank Amy Witter for analyzing iron concentrations. This work was supported by the National Science Foundation.

\section{LITERATURE CITED}

Ausubel FM, Brent R, Kingston RE, Moore DD, Seidman JG, Smith JA, Struhl K (1992) Current protocols in molecular biology. 2 vols. Greene Publishing Associates, WileyInterscience, New York

Bassler BL, Wright M, Silverman MR (1994) Multiple signalling systems controlling expression of luminescence in Vibrio harveyi: sequence and function of genes encoding a second sensory pathway. Mol Microbiol 13:273-286

Brand LE (1991) Minimum iron requirements of marine phytoplankton and the implications for the biogeochemical control of new production. Limnol Oceanogr 36:1756-1771

Christiansen T, Nielsen J (2002) Growth energetics of an alkaline serine protease-producing strain of Bacillus clausii during continuous cultivation. Bioprocess Biosyst Eng 24: 329-339

Church MJ, Hutchins DA, Ducklow HW (2000) Limitation of bacterial growth by dissolved organic matter and iron in the Southern Ocean. Appl Environ Microbiol 66:455-466

Crawford DL, Crawford RL (1976) Microbial degradation of lignocellulose: the lignin component. Appl Environ Microbiol 31:714-717

del Giorgio PA, Cole JJ (2000) Bacterial energetics and growth efficiency. In: Kirchman DL (ed) Microbial ecology of the oceans. Wiley-Liss, New York, p 289-325

Ducklow H (2000) Bacterial production and biomass in the oceans. In: Kirchman DL (ed) Microbial ecology of the oceans. Wiley-Liss, New York, p 85-120

Goldman JC, Dennett MR (2000) Growth of marine bacteria in batch and continuous culture under carbon and nitrogen limitation. Limnol Oceanogr 45:789-800

Hutchins DA, Campbell BJ, Cottrell MT, Takeda S, Cary SC (2001) Response of marine bacterial community composition to iron additions in three iron-limited regimes. Limnol Oceanogr 46:1535-1545 
Johnson KS, Gordon RM, Coale KH (1997) What controls dissolved iron concentrations in the world ocean? Mar Chem 57:137-161

Keller MD, Bellows WK, Guillard RRL (1988) Microwave treatment for sterilization of phytoplankton culture media. J Exp Mar Biol Ecol 117:279-283

Kirchman DL (2000) Uptake and regeneration of inorganic nutrients by marine heterotrophic bactera. In: Kirchman DL (ed) Microbial ecology of the oceans. Wiley-Liss, New York, p 261-288

Kirchman DL, Wheeler PA (1998) Uptake of ammonium and nitrate by heterotrophic bacteria and phytoplankton in the sub-Arctic Pacific. Deep-Sea Res 45:347-365

Kirchman DL, Ducklow HW, McCarthy JJ, Garside C (1994) Biomass and nitrogen uptake by heterotrophic bacteria during the spring phytoplankton bloom in the NorthAtlantic Ocean. Deep-Sea Res 41:879-895

Kirchman DL, Meon B, Cottrell MT, Hutchins DA, Weeks D, Bruland KW (2000) Carbon versus iron limitation of bacterial growth in the California upwelling regime. Limnol Oceanogr 45:1681-1688

Marr AG (1991) Growth rate of Escherichia coli. Microbiol Rev 55:316-333

Martin JH, Gordon RM, Fitzwater SE (1991) The case for iron. Limnol Oceanogr 36:1793-1802

Montgomery MT, Kirchman DL (1993) Role of chitin-binding proteins in the specific attachment of the marine bacterium Vibrio harveyi to chitin. Appl Environ Microbiol 59: 373-379

Neijssel OM, DeMattos MJT, Tempest DW (1996) Growth yield and energy distribution. In: Neidhardt FC, Curtiss R, Ingraham JL, Lin ECC and 6 others (eds) Escherichia coli and Salmonella. ASM Press, Washington, DC, p 1683-1692

Packard TT, Williams PJL (1981) Rates of respiratory oxygenconsumption and electron-transport in surface seawater from the northwest Atlantic. Oceanol Acta 4:351-358

Pakulski JD, Coffin RB, Kelley CA, Holder SL, Downer R, Aas P, Lyons MM, Jeffrey WH (1996) Iron stimulation of Antarctic bacteria. Nature 383:133-134

Price NM, Harrison GI, Hering JG, Hudson RJ, Nirel PMV, Palenik B, Morel FMM (1989) Preparation and chemistry of the artificial algal culture medium aquil. Biol Oceanogr 6:443-461

Rappé MS, Connon SA, Vergin KL, Giovannoni SJ (2002)

Editorial responsibility: Otto Kinne (Editor),

Oldendorf/Luhe, Germany
Cultivation of the ubiquitous SAR11 marine bacterioplankton clade. Nature 418:630-633

Sarmiento JL, LeQuere C (1996) Oceanic carbon dioxide uptake in a model of century-scale global warming. Science 274:1346-1350

Sarmiento JL, Hughes TMC, Stouffer RJ, Manabe S (1998) Simulated response of the ocean carbon cycle to anthropogenic climate warming. Nature 393:245-249

Schmidt MA, Hutchins DA (1999) Size-fractionated biological iron and carbon uptake along a coastal to offshore transect in the NE Pacific. Deep-Sea Res Part II 46:2487-2503

Schulz GE, Schirmer RH (1979) Principles of protein structure, 2nd edn. Springer-Verlag, New York

Seitzinger SP, Sanders RW, Styles R (2002) Bioavailability of DON from natural and anthropogenic sources to estuarine plankton. Limnol Oceanogr 47:353-366

Sherry ND, Boyd PW, Sugimoto K, Harrison PJ (1999) Seasonal and spatial patterns of heterotrophic bacterial production, respiration, and biomass in the subarctic NE Pacific. Deep-Sea Res Part II 46:2557-2578

Sunda WG, Huntsman SA (1995) Iron uptake and growth limitation in oceanic and coastal phytoplankton. Mar Chem 50:189-206

Svitil AL, Chadhain SMN, Moore JA, Kirchman DL (1997) Chitin degradation proteins produced by the marine bacterium Vibrio harveyi growing on different forms of chitin. Appl Environ Microbiol 63:408-413

Thingstad TF (2000) Control of bacterial growth in idealized food webs. In: Kirchman DL (ed) Microbial ecology of the oceans. Wiley-Liss, New York, p 229-260

Tortell PD, Maldonado MT, Price NM (1996) The role of heterotrophic bacteria in iron-limited ocean ecosystems. Nature 383:330-332

Tortell PD, Maldonado MT, Granger J, Price NM (1999) Marine bacteria and biogeochemical cycling of iron in the oceans. FEMS Microbiol Ecol 29:1-11

Vallino JJ, Hopkinson CS, Hobbie JE (1996) Modeling bacterial utilization of dissolved organic matter: optimization replaces Monod growth kinetics. Limnol Oceanogr 41: 1591-1609

Van den Berg CMG, Nimmo M, Abollino O, Mentasti E (1991) The determination of trace levels of iron in seawater using adsorptive cathodic stripping voltammetry. Electroanalysis 3:477-484

Submitted: July 25, 2002; Accepted: December 17, 2002

Proofs received from author(s): March 3, 2003 